Ethiopian Journal of Environmental Studies \& Management 7 Suppl.: 840 - 849, 2014.

ISSN:1998-0507

doi: http://dx.doi.org/10.4314/ejesm.v7i2.4S

Submitted: September 26, 2014

Accepted: November 19, 2014

\title{
EFFECTS OF GALLIC ACID (ISOLATED FROM GRAPE RIND) ON SERUM BIOCHEMISTRY, HISTOLOGY AND HAEMATOLOGY OF Aspergillus flavus CHALLENGED BROILERS
}

\author{
LAWAL, M. AND *BOLU, S.A. \\ Department of Animal Production, University of Ilorin, Ilorin, Nigeria
}

\begin{abstract}
A study was conducted to investigate the effects of gallic acid on broiler chicks challenged with Aspergillus flavus for ten weeks. One hundred day old broiler chicks were randomized into six treatments, each of the treatments were replicated three times with five birds per replicate with standard, positive, negative control and groups which incorporated gallic acid at 1, 2, and 3ml $/ L$ respectively in drinking water. The response of broiler chicks to the challenge were assessed in terms of their histology, haematology and specific serum constituents. Histological results of the organs (lungs, liver and ileum) during the treatment phase showed normal morphological patterns for liver and lungs for broiler chicks subjected to $1 \mathrm{ml} / \mathrm{l}$ of gallic acid but not for ileum while those on gallic acid at $2 \mathrm{ml} / \mathrm{l}$ showed normal organ morphology for all the organs investigated whereas those subjected to $3 \mathrm{ml} / \mathrm{l}$ gallic acid showed abnormal morphology for liver, lungs with the ileum exclusive. The post-treatment result showed normal morphology for all the organs subjected to 1, 2, $3 \mathrm{ml} / \mathrm{l}$ gallic acid respectively. Similarly, birds raised on commercial anti-fungal showed normal organ morphology during the treatment and posttreatment phase compared with the positive control. Conversely, birds challenged with Aspergillus flavus without gallic acid inclusion (negative control) showed abnormal morphological pattern for all the organs investigated. Moreso, there were no adverse effects of gallic acid on broiler chicks health as determined from the analysis of various haematological parameters and serum metabolites. The results indicated that gallic acid inclusion at $2 \mathrm{ml} / \mathrm{l}$ in drinking water could successfully replace anti-fungal drugs and harness the challenges of aspergillosis in poultry birds.
\end{abstract}

\section{Introduction}

Aflatoxins are mycotoxins produced as secondary metabolites of some fungi, they are a group of 18 or more related compounds. They are known as the most toxic potent carcinogens naturally produced by fungal moulds, mainly A. flavus and A. parasiticus (Gustavo et al., 2007). Aflatoxins are stable under normal food processing conditions and can therefore be present not only in food and feed but also in processed products and threatening both human and animal health as they are known to be the most potent carcinogens (Nizam and Oguz, 2003). These toxins have been reported to be responsible for incidence of high mortality in livestock and some cases of death in human being (Park et al., 2004). The toxins released during A. flavus infection depress production parameters and, specifically, cause impaired growth in poultry, while the immunosuppressive effect predisposes the animals to many secondary infections from other pathogens, such as fungi, bacteria and viruses. 
Currently, the most common methods of suppressing pathogens in animals have been treatment with antibiotics as a therapeutic agent and use of growth promoters, because these are readily available. However, the use of antibiotics in the treatment of animal disease is currently a subject of public health concern, as the development of resistant strains (superbugs) is a potential danger to humans (Park et al., 2004). With the recent ban on the use of sub-therapeutic antibiotics in the production of livestock by the EU (Elbarkouky et al., 2010), research attention has shifted towards the development of positive alternatives.

The use of plants for medicinal purposes predates the introduction of antibiotics and other modern drugs, and there has been renewed interest in natural products from higher plants which contain active ingredients of medicinal value. Scarcity and sale of fake and adulterated pharmaceutical drugs, which has been on the increase especially in the developing world, has made ethnoveterinary approaches even more attractive. The use of numerous plant extracts, spices and their constituents may provide an alternative way to prevent fungal growth and mycotoxins formation (Vagi et al., 2005). Grape seeds and skins are considered good sources of polyphenolic tannins that provide the astringent taste to wine. The phenolic acid; gallic acid and monomers - catechin and epicatechin are the main phenolic compounds in grape seeds (Palma and Taylor, 1999).

Gallic acid is a trihydroxybenzoic acid, is found in gallnuts, witch hazel and other plants (Reynolds and Wilson, 1991). Gallic acid seems to have anti-fungal and anti-viral properties. This study investigated the efficacy of the levels of gallic acid necessary for inhibiting aflatoxin in broilers challenged with A. flavus.

\section{Materials and Methods \\ Plant Material (Vinis vitifera)}

The rind of grape used for the experiment was peeled off from 140 pieces of grape fruit sourced from Ilorin metropolis in Kwara State. Ilorin is located at latitude $08^{\circ} 29^{\prime} \mathrm{N}$ and longitude $04^{\circ} 35^{\prime} \mathrm{E}$. The elevation is $305 \mathrm{~m}$ 1001 , the annual temperature range is $22-34^{\circ} \mathrm{C}$ and the annual precipitation is $80-12 \mathrm{~mm}$.

\section{Extraction and Isolation of Gallic Acid}

The air-dried rind of grape fruit $(3.5 \mathrm{~kg})$ was percolated with 10 litres of methanol in a flat-bottomed flask at room temperature for 5 days. The solution was decanted and concentrated to evaporate the solvent using a rotary evaporator at a temperature of $80^{\circ} \mathrm{C}$ for 2 hrs to yield a brown gummy residue $(350 \mathrm{~g})$. An aqueous suspension of this residue was extracted 4 times each with $150 \mathrm{ml}$ of butanol and chloroform, respectively. The extracts were combined and evaporated under reduced pressure using rotary evaporator to give chloroform (132.5g) and butanol (92.5g) fractions. The butanol extract (92.5g) was poured into a column chromatography eluting with $250 \mathrm{ml}$ of chloroform followed by gradient mixtures of chloroform - ethyl acetate at $100 \mathrm{ml}$, ethyl acetate - methanol at $100 \mathrm{ml}$ and methanol continuously at $100 \mathrm{ml}$ until a clear fraction was eluted using a column chromatography to give four fractions of methanol.

\section{Source of A. flavus}

A. flavus spores were collected from the Department of Microbiology, University of Ilorin and grown on a plate on a culture of Potato Dextrose Agar (PDA), and incubated at $28^{\circ} \mathrm{C}$ for seven days.

\section{Experimental Animals and Treatment}

100 day old broiler chicks were raised in a metabolic cage for 10 weeks and randomized into 6 treatments. Each of the treatments was replicated 3 times with 5 birds per replicate. The treatments were designed as follows (shown in Table 1) and the birds fed same diet ad libitum (Table 2 and 3 ). 
Table 1: Composition of Experimental Treatment

\begin{tabular}{ccccc}
\hline & $\begin{array}{l}\text { Treatment Infected with } \\
\text { Aspergillus flavus }\end{array}$ & $\begin{array}{l}\text { Supplemented } \\
\text { with Gallic Acid }\end{array}$ & $\begin{array}{l}\text { Supplemented } \\
\text { with Antifungal } \\
\text { (Furacare) }\end{array}$ & Remark \\
\hline 1 & - & - & - & Positive control \\
2 & + & - & + & Anti-fungal \\
3 & + & - & - & Negative control \\
4 & + & + & - & $1 \mathrm{ml} / 1$ \\
5 & + & + & - & $2 \mathrm{ml} / 1$ \\
6 & + & + & - & $3 \mathrm{ml} / 1$ \\
\hline
\end{tabular}

Table 2: Composition of Experimental Diet for Broiler Starter (\%DM)

\begin{tabular}{lc}
\hline Ingredients & \% Inclusion \\
\hline Maize & 50.00 \\
Wheat offal & 2.00 \\
BDG & 5.00 \\
Fish meal (72\%) & 1.50 \\
Soybean meal & 27.30 \\
Palm kernel cake & 5.00 \\
Blood meal & 3.00 \\
Palm oil & 3.00 \\
Bone meal & 2.00 \\
Oyster shell & 0.50 \\
Premix & 0.25 \\
Salt & 0.25 \\
Lysine & 0.10 \\
Methionine & 0.10 \\
\hline Total & 100 \\
\hline
\end{tabular}

Nutrient composition Protein: 23\%; Energy: 2,951.18Kcal; fibre: 4.5\%; Calcium: 1.11\%; Phosphorus: 0.71

Table 3: Composition of Experimental Diet for Broiler Finisher (\%DM)

\begin{tabular}{lr}
\hline \multicolumn{1}{c}{ Ingredients } & \% Inclusion \\
\hline Maize & 55.50 \\
Corn bran & 6.76 \\
Soybean meal & 23.00 \\
Palm kernel cake & 5.00 \\
Blood meal & 3.33 \\
Palm oil & 3.00 \\
Bone meal & 2.00 \\
Oyster shell & 0.80 \\
Premix & 0.25 \\
Salt & 0.25 \\
Lysine & 0.10 \\
Methionine & 0.10 \\
\hline Total & 100 \\
\hline
\end{tabular}

Nutrient composition Protein: 19.4\%; Energy: 3,116.17Kcal; fibre: 4.3\%; Calcium: 1.0\%; Phosphorus: 0.76

Inoculation of Chick Drinking Water with A. flavus Spores

Birds were placed on the same diet formulated to meet the NRC (1994) nutrient requirement for broilers. The birds were vaccinated against gumboro and Newcastle comprising of two phase. 
During week 2, the broiler chicks in the infected groups were challenged with $A$. flavus $\left(2.7 \times 10^{6}\right.$ spores $\left./ \mathrm{ml}\right)$ via drinking water. A confirmatory test of the respiratory tract was carried out by eviscerating each bird in the infected groups for caseous foci or yellow deposits in lungs, trachea and air sacs during histological examination (Bolu, et al., 2014).Each bird in the infected-treated groups were given dose specified to each groups via drinking water for 14-days immediately after the first clinical findings.

\section{Data Collection}

At the fourth and tenth week of the experiment, a bird was randomly selected from each replicate and euthanized (university ethical committee approved method of slaughtering) by severing the jugular vein and blood samples were collected into vials containing EDTA. The red blood cell and white blood cell counts were determined by a hemocytometer method; hematocrit and hemoglobin values were measured by microhematocrit and cyanmethemoglobin methods, respectively (Kececi et al., 1998). Also, blood samples were collected in non-heparinised tube from one bird per replicate by severing the jugular vein and the blood was centrifuged to obtain serum. Serum samples were analyzed for total protein, albumin, creatine, aspartate aminotransferase (AST) and alanine aminotransferase (ALT) using the kit package manufactured by Pars Azmoon Company, Tehran, Iran.

After slaughtering, the birds were dressed and dissected. The organs required for histology were quickly dissected, and preserved in $10 \%$ formalin solution. The tissues were trimmed, fixed in Bouin fixation

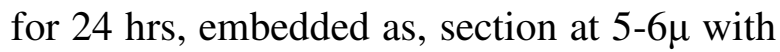

a microton and stained with haematoxlin and eosin. The histological study was carried out according to the described method by King et al. (1980).

\section{Statistical Analysis}

The experimental design used was a Completely Randomized Design (Steel and Torrie, 1980). Data collected was subjected to analysis of variance and significantly different means compared using Duncan Multiple Range Test (Duncan, 1955).

\section{Results and Discussion}

The results of in vitro inhibition studies established gallic acid could as a potent $A$. flavus mycotoxin inhibition which could ameliorate the effects of aflatoxicosis in farm animals. Gallic acid enhanced the proper development and growth of these organs and tissues especially in disease condition. From the result in Table 4, it was observed that the organs (liver, lungs and ileum) in the treated group of gallic acid at $1 \mathrm{ml} / 1$, and $2 \mathrm{ml} / 1$, respectively were not affected by $A$. flavus while in the $3 \mathrm{ml} / \mathrm{l}$ of gallic acid treated group, the mild alterations in the liver and lungs may be attributed to heavy infestation of the organs by the A. flavus before treatment or strong potency of gallic acid. However, the negative control group showed mild inflammation of the lungs, liver and ileum tissue. This means that the use of antibiotics and other alternatives to antibiotic drugs discourages the growth of these pathogenic microbes from affecting the liver; this is in line with the work of Bolu et al. (2013). In this study, the birds challenged with A. flavus without gallic acid (negative control) showed abnormal morphological pattern for all the organs investigated. 
Table 4: Effects of Treatment on Histology of Liver, Lungs and Ileum of Broiler Chickens

\begin{tabular}{|c|c|c|}
\hline Groups & Organs & Description of Organs \\
\hline \multirow[t]{3}{*}{ Positive Control } & Liver & Normal liver tissue; normochromic \\
\hline & Lungs & Normal lung tissue \\
\hline & Ileum & Normal ileum tissue \\
\hline \multirow{3}{*}{$\begin{array}{l}\text { Infected and Treated With Anti- } \\
\text { Fungal }\end{array}$} & Liver & Normal liver tissue \\
\hline & Lungs & $\begin{array}{l}\text { Normal but with slight architectural } \\
\text { disruption }\end{array}$ \\
\hline & Ileum & Normal tissue \\
\hline \multirow[t]{3}{*}{ Negative Control } & Liver & Inflamed and hyperchromic tissue \\
\hline & Lungs & Mildly inflamed lung tissue \\
\hline & Ileum & Mildly inflamed and degenerated. \\
\hline \multirow[t]{3}{*}{$\begin{array}{l}\text { Infected and Treatedwith Gallic } \\
\text { Acid } 1 \mathrm{ml} / \mathrm{L}\end{array}$} & Liver & $\begin{array}{l}\text { Normal liver tissue with mild polymorph } \\
\text { infilteration }\end{array}$ \\
\hline & Lungs & Normal lung tissue \\
\hline & Ileum & Mildly hyperchromic tissue \\
\hline \multirow{3}{*}{$\begin{array}{l}\text { Infected and Treatedwith Gallic } \\
\text { Acid } 2 \mathrm{ml} / \mathrm{L}\end{array}$} & Liver & Normal \\
\hline & Lungs & Normal \\
\hline & Ileum & Normal \\
\hline \multirow{3}{*}{$\begin{array}{l}\text { Infected and Treated with Gallic } \\
\text { Acid } 3 \mathrm{ml} / \mathrm{L}\end{array}$} & Liver & Mild hepatic degeneration/hyperchromic \\
\hline & Lungs & Mild lung tissue inflammation \\
\hline & Ileum & Normal \\
\hline
\end{tabular}

Table 5: Effects of Treatment on the Haematology of Broiler Chicks

\begin{tabular}{llllllll}
\hline Items & $\begin{array}{l}\text { Positive } \\
\text { Control }\end{array}$ & $\begin{array}{c}\text { Anti- } \\
\text { Fungal }\end{array}$ & $\begin{array}{l}\text { Negative } \\
\text { Control }\end{array}$ & $\begin{array}{l}\text { Gallic } \\
\text { Acid1ml/L }\end{array}$ & $\begin{array}{l}\text { Gallic } \\
\text { Acid2ml/L }\end{array}$ & $\begin{array}{l}\text { Gallic } \\
\text { Acid3ml/L }\end{array}$ & SEM \\
\hline PCV $(\%)$ & $30.00^{\mathrm{b}}$ & $27.00^{\mathrm{b}}$ & $22.00^{\mathrm{a}}$ & $35.33^{\mathrm{c}}$ & $38.00^{\mathrm{c}}$ & $29.00^{\mathrm{b}}$ & 0.82 \\
RBC $\left(\mathrm{x} 10^{12}\right)$ & $5.50^{\mathrm{ab}}$ & $5.90^{\mathrm{b}}$ & $5.27^{\mathrm{a}}$ & $5.89^{\mathrm{b}}$ & $5.30^{\mathrm{a}}$ & $5.82^{\mathrm{b}}$ & 0.076 \\
WBC $\left(\times 10^{9}\right)$ & $7.93^{\mathrm{b}}$ & $10.47^{\mathrm{d}}$ & $8.53^{\mathrm{bc}}$ & $6.07^{\mathrm{a}}$ & $5.63^{\mathrm{a}}$ & $10.30^{\mathrm{cd}}$ & 0.34 \\
Haemoglobin & $10.40^{\mathrm{ab}}$ & $10.97^{\mathrm{bc}}$ & $9.90^{\mathrm{a}}$ & $11.57^{\mathrm{c}}$ & $11.53^{\mathrm{c}}$ & $10.37^{\mathrm{ab}}$ & 0.14 \\
concentration (g/dl) & & & & & & & \\
Neutrophils (\%) & $50.00^{\mathrm{c}}$ & $39.30^{\mathrm{abc}}$ & $35.67^{\mathrm{ab}}$ & $33.00^{\mathrm{a}}$ & $48.67^{\mathrm{bc}}$ & $38.00^{\mathrm{abc}}$ & 2.38 \\
Lymphocyte (\%) & $48.00^{\mathrm{a}}$ & $58.67^{\mathrm{ab}}$ & $62.33^{\mathrm{ab}}$ & $65.00^{\mathrm{b}}$ & $50.00^{\mathrm{a}}$ & $60.00^{\mathrm{ab}}$ & 2.46 \\
Eosinophils (\%) & 1.33 & 1.33 & 1.33 & 1.33 & 1.33 & $1.33^{\mathrm{NS}}$ & 0.24 \\
Basophils (\%) & 0.67 & 0.67 & 0.67 & 0.67 & 0.00 & $0.67^{\mathrm{NS}}$ & 0.17 \\
\hline
\end{tabular}

NB: a-b-c means in rows not sharing common letters differ significantly $(\mathrm{P}<0.05)$.

Changes in the physiological state often reflect alteration of haematological values. Therefore blood indices are a fundamental tool used to monitor the effects of therapeutic, nutritional and environmental management in human and veterinary medicine (Toghyani et al., 2011). The effect of treatment on blood haematology of broiler chick is presented in Table 5 .
Eeosinophils and basophils were not affected $(\mathrm{P}>0.05)$ among treatments. Packed cell volume $(\mathrm{PCV})$ differs markedly $(\mathrm{P}<0.05)$ among treatments. (PCV) is the volume of sedimented red cells found in $100 \mathrm{ml}$ of blood (Ayodele, 2009). Birds in the negative control group recorded the lowest value compared to the group treated with gallic acid at $2 \mathrm{ml} / 1$ which recorded the highest 
value among the treatments. However, the positive control group, anti-fungal treated group and gallic acid at $3 \mathrm{ml} / \mathrm{l}$ were similar in values. The result obtained for haemoglobin concentration $(\mathrm{Hb})$ showed significant difference $(\mathrm{p}<0.05)$ among the treatments; birds fed gallic acid at $1 \mathrm{ml} / 1$ and $2 \mathrm{ml} / 1$, respectively had similar values. Lower than normal $\mathrm{Hb}$ values usually indicate anaemia while higher than normal values would indicate iron overload or excessive production of red blood cells (Ayodele, 2009). Red blood cells values were higher in the anti-fungal treated group and gallic acid at $1 \mathrm{ml} / 1$ treated group. However, under the negative control group RBC value was the lowest. This finding is in line with the findings of Bolu et al.,(2013). White blood cell value in this study shows a significant difference $(p<0.05)$ among treatments. The gallic acid treated group at $1 \mathrm{ml} / 1$ and $2 \mathrm{ml} / 1$ respectively recorded the least values compared to the positive and negative control groups which were similar. On the other hand, anti-fungal and gallic acid at $3 \mathrm{ml} / \mathrm{l}$ treated group recorded the highest value. An increase in WBC shows a sign of infection (Table 5). An increase in the total number of lymphocytes in circulation may be seen in a majority of viral infections. In this study, birds in the positive control and gallic acid at $2 \mathrm{ml} / 1$ treated groups recorded the lowest of values compared to the other groups which are similar and higher in value. Neutrophils are often elevated in an active infection (Akinsanya, 2010). In this study, birds in the positive control group and gallic acid at $2 \mathrm{ml} / 1$ showed the highest value while the lowest value is recorded in gallic acid treated group at $1 \mathrm{ml} / 1$. low levels are indicative of a good state of health. However, the negative control group, anti-fungal and gallic acid treated group at $3 \mathrm{ml} / 1$ were similar.

The effect of serum biochemistry is presented in Table 6, albumin was not affected by the treatments. Aberration in the serum creatinine and uric acid could be early pointer to depressed liver and kidney function (Tillson, 2003). The positive control group recorded the lowest value compared to the negative control. A rise in serum activity of creatine kinase was observed in chickens after aflatoxin ingestion, possibly because of tissue damage and a resulting leakage of enzymes into the blood (Bailey et al., 1998). Blood serum protein reflects the condition of an organism and the changes happening to it under influence of internal and external factors (Babalola et al., 2009). The total protein recorded the highest and similar values in the positive control and gallic acid at $1 \mathrm{ml} / 1$ group while the lowest value was recorded in the group treated with gallic acid at $2 \mathrm{ml} / 1$, however, the negative control, antifungal and gallic acid at $3 \mathrm{ml} / 1$ groups were similar. The observed reduction in serum concentration of total protein is in line with the findings of Tung et al., (1975) in which group of animals fed aflatoxin showed reduction in serum concentration of total protein which result to impaired protein synthesis resulting from the hepatotoxicity seen in aflatoxicosis (Bailey et al., 1998). ALT is an enzyme present in higher concentrations in the liver than in the muscles. An elevation is more specific for liver disease. In this study the negative control group recorded the highest value compared to the positive control group with the lowest value. On the other hand, the treated groups recorded values that are similar among the treatment but comparatively lower to the negative control group. The increase in the negative control group corroborate with the work of Zaky et al., (1998) who reported that with continued exposure intra-hepatic biliary epithelial hyperplasia occurred as an attempt to regenerate the hepatic parenchyma when the parenchymal cells themselves have lost their capacity. 
Table 6: Effects of Treatment on Serum Biochemistry of Broiler Chicks

\begin{tabular}{llllllll}
\hline Items & $\begin{array}{l}\text { Positive } \\
\text { Control }\end{array}$ & $\begin{array}{l}\text { Anti- } \\
\text { Fungal }\end{array}$ & $\begin{array}{l}\text { Negative } \\
\text { Control }\end{array}$ & $\begin{array}{l}\text { Gallic Acid } \\
\text { @ 1ml/L }\end{array}$ & $\begin{array}{l}\text { Gallic Acid } \\
\text { @ 2ml/L }\end{array}$ & $\begin{array}{l}\text { Gallic Acid } \\
\text { @ 3ml/L }\end{array}$ & SEM \\
\hline Creatinine & $113.67^{\mathrm{a}}$ & $178.67^{\mathrm{bc}}$ & $239.00^{\mathrm{d}}$ & $153.33^{\mathrm{abc}}$ & $188.00^{\mathrm{c}}$ & $143.00^{\mathrm{ab}}$ & 7.44 \\
Protein & $184.67^{\mathrm{b}}$ & $157.00^{\mathrm{ab}}$ & $147.33^{\mathrm{ab}}$ & $181.33^{\mathrm{ab}}$ & $136.00^{\mathrm{a}}$ & $173.00^{\mathrm{ab}}$ & 7.71 \\
Albumin & 55.33 & 50.67 & 47.33 & 54.33 & 48.67 & $51.33^{\mathrm{NS}}$ & 1.73 \\
ALT & $41.00^{\mathrm{a}}$ & $66.00^{\mathrm{bc}}$ & $96.00^{\mathrm{d}}$ & $62.33^{\mathrm{bc}}$ & $72.67^{\mathrm{c}}$ & $56.67^{\mathrm{b}}$ & 1.86 \\
AST & $48.00^{\mathrm{a}}$ & $67.67^{\mathrm{b}}$ & $87.00^{\mathrm{c}}$ & $61.33^{\mathrm{b}}$ & $65.33^{\mathrm{b}}$ & $69.00^{\mathrm{b}}$ & 1.85 \\
\hline
\end{tabular}

NB: a-b-c-d means in rows not sharing common letters differ significantly $(\mathrm{P}<0.05)$.

The effect of gallic acid on serum biochemistry, histology and haematology during the post-treatment of A. flavus challenged broiler chickens was observed for four weeks after treatment. It is well known that animals restricted in growth due to low nutrient intake resulting from a low quality diet or environmental or disease stress will exhibit an increased rate of gain and enhanced feed utilization when the stresses are eliminated.

From the result of histology, it was observed that gallic acid enhanced the proper development and growth of these organs and Table 7: Effect of Treatment on Histology of Liver, Lungs and Ileum of Finishing Broiler chickens

\begin{tabular}{lll}
\hline Groups & Organs & Description \\
\hline Positive Control & Liver & Normal \\
& Lungs & Normal \\
& Nleum & Normal \\
\hline Infected And Treated & Liver & Moderately distorted architecture \\
With Anti-Fungal & Lungs & $\begin{array}{l}\text { Normal lungs with highly eosinophilic smooth } \\
\text { muscle }\end{array}$ \\
& Ileum & Normal architecture with darkly staining cells \\
\hline Negative Control & Liver & Abnormal structure. \\
& Lungs & Normal structure with few ulceration of atria and \\
& & smooth muscle. \\
& Severely distorted structure, hypochromic cells \\
\hline Treated with gallic acid at $1 \mathrm{ml} / 1$ & Liver & Normal architecture \\
& Lungs & Normal architectural structure \\
& Ileum & Normal tissue \\
\hline Treated with gallic acid at $2 \mathrm{ml} / 1$ & Liver & Normal liver portal tract \\
& Lungs & Normal lungs with parabronchi and atria filled by \\
& & eosinophilic substance \\
& Ileum & Normal tissue \\
\hline Treated with gallic acid at $3 \mathrm{ml} / 1$ & Liver & Normal portal tract \\
& Lungs & Normal tissue \\
& Ileum & Normal tissue \\
\hline & & \\
\hline
\end{tabular}

tissues especially in disease condition. The positive control and the gallic acid treated group at $1 \mathrm{ml} / 1,2 \mathrm{ml} / 1$ and $3 \mathrm{ml} / 1$, respectively showed normal architectural structure of the organs compared to the anti-fungal treated group (standard) which depicted a distortion in the portal tract of the liver. This finding conforms to the report of Ravindran, (2006) who reported that alternative sources of antibiotics can prevent proliferation of pathogenic bacteria and modulation of indigenous bacteria so that the health, immune status and performance are improved. 
Table 8: Effect of Treatment on Haematology of Finishing Broiler

\begin{tabular}{|c|c|c|c|c|c|c|c|}
\hline $\begin{array}{l}\text { Haematological } \\
\text { Indices }\end{array}$ & $\begin{array}{l}\text { Positive } \\
\text { Control }\end{array}$ & $\begin{array}{l}\text { Treated } \\
\text { With Anti- } \\
\text { Fungal }\end{array}$ & $\begin{array}{l}\text { Negative } \\
\text { Control }\end{array}$ & $\begin{array}{l}\text { Gallic } \\
\text { Acid@ } \\
1 \mathrm{ml} / 1\end{array}$ & $\begin{array}{l}\text { Gallic } \\
\text { Acid@ } \\
2 \mathrm{ml} / 1\end{array}$ & $\begin{array}{l}\text { Gallic } \\
\text { Acid@ } \\
3 \mathrm{ml} / 1\end{array}$ & SEM \\
\hline $\mathrm{PCV}(\%)$ & $24.67^{\mathrm{ab}}$ & $23.67^{\mathrm{ab}}$ & $32.67^{\mathrm{b}}$ & $29.67^{\mathrm{ab}}$ & $29.23^{\mathrm{ab}}$ & $32.00^{\mathrm{ab}}$ & 2.22 \\
\hline $\operatorname{RBC}\left(\times 10^{12}\right)$ & $1.47^{\mathrm{a}}$ & $1.54^{\mathrm{ab}}$ & $2.05^{\mathrm{ab}}$ & $1.67^{\mathrm{ab}}$ & $1.68^{\mathrm{ab}}$ & $2.14^{\mathrm{b}}$ & 0.11 \\
\hline WBC $\left(x 10^{9}\right)$ & $66.70^{\mathrm{a}}$ & $84.73^{\mathrm{b}}$ & $96.27^{\mathrm{b}}$ & $93.50^{\mathrm{b}}$ & $94.93^{\mathrm{b}}$ & $94.33^{\mathrm{b}}$ & 2.78 \\
\hline Neutrophils (\%) & $0.67^{\mathrm{a}}$ & $2.33^{\mathrm{bc}}$ & $3.00^{\mathrm{c}}$ & $1.33^{\mathrm{ab}}$ & $1.33^{\mathrm{ab}}$ & $2.67^{\mathrm{c}}$ & 0.22 \\
\hline Lymphocyte (\%) & $95.67^{\mathrm{ab}}$ & $97.33^{\mathrm{b}}$ & $96.00^{\mathrm{ab}}$ & $96.67^{\mathrm{ab}}$ & $97.67^{\mathrm{b}}$ & $94.67^{\mathrm{a}}$ & 0.40 \\
\hline Haematocrit (g/dl) & 10.67 & 10.53 & 12.97 & 11.57 & 11.27 & 12.90 & 0.43 \\
\hline Eosinophils (\%) & 0.33 & 0.67 & 0.00 & 0.33 & 0.00 & 0.00 & 0.14 \\
\hline Basophils (\%) & 0.00 & 0.33 & 0.33 & 0.33 & 0.00 & 0.67 & 0.16 \\
\hline Monocytes (\%) & 1.67 & 1.00 & 1.00 & 1.33 & 1.00 & 2.00 & 0.22 \\
\hline
\end{tabular}

$a, b, c$ means in rows not sharing common letters differ significantly $(\mathrm{P}<0.05)$.

The result of treatment on haematology of finishing broiler is presented in Table 8 . Haemoglobin concentration, eosinophils, basophils and monocytes were not significantly affected $(\mathrm{p}>0.05)$ by the treatment. PCV, RBC, WBC, neutrophils and lymphocyte were significantly influenced $(\mathrm{p}<0.05)$ by the treatment. This observation agrees with finding of Toghyani et al., (2011), that Changes in the physiological state often reflects alteration of haematological values. The negative control group recorded higher values in haematological parameters as reflected as alteration of organs in histology. On the contrary, the treated group of anti-fungal, gallic acid at $1 \mathrm{ml} / 1$ and $2 \mathrm{ml} / 1$ recorded values that are lower and similar with the exception of the group with gallic acid at $3 \mathrm{ml} / \mathrm{l}$ which deviated the trend in red blood cell and neutrophils.

TABLE 9: Effect of Treatment on Serum Biochemistry of Finishing Broiler

\begin{tabular}{llllllll}
\hline Parameters & $\begin{array}{l}\text { Positive } \\
\text { Control }\end{array}$ & $\begin{array}{l}\text { Anti- } \\
\text { Fungal }\end{array}$ & $\begin{array}{l}\text { Negative } \\
\text { Control }\end{array}$ & $\begin{array}{l}\text { Gallic } \\
\text { Acid1ml/L }\end{array}$ & $\begin{array}{l}\text { Gallic } \\
\text { Acid2ml/L }\end{array}$ & $\begin{array}{l}\text { Gallic } \\
\text { Acid3ml/L }\end{array}$ & SEM \\
\hline Creatinine & 0.13 & 0.13 & 0.073 & 0.13 & 0.76 & $0.27^{\mathrm{NS}}$ & 0.16 \\
Protein & 119.33 & 163.67 & 152.33 & 107.33 & 183.00 & $156.66^{\mathrm{NS}}$ & 13.52 \\
Albumin & 21.67 & 21.00 & 20.00 & 15.33 & 22.67 & $17.67^{\mathrm{NS}}$ & 1.75 \\
ALT & 11.00 & 19.67 & 15.67 & 11.00 & 24.67 & $16.00^{\mathrm{NS}}$ & 2.97 \\
AST & $39.67^{\mathrm{a}}$ & $68.67^{\mathrm{b}}$ & $79.33^{\mathrm{bc}}$ & $59.00^{\mathrm{ab}}$ & $102.00^{\mathrm{c}}$ & $71.67^{\mathrm{b}}$ & 4.80 \\
\hline
\end{tabular}

NB: a-b-c means in rows not sharing common letters differ significantly $(\mathrm{P}<0.05)$

The result of treatment on serum biochemistry of finishing broiler is presented in Table 9. Creatinine, total protein, albumin and ALT were not significantly affected ( $>0.05)$ by the treatment. AST was significantly influenced $(\mathrm{p}<0.05)$ by the treatment. Birds in the positive control group recorded the least value compared to the negative control, while the highest value was recorded for gallic acid at $2 \mathrm{ml} / \mathrm{l}$ treated group. AST is an enzyme found primarily in the heart, liver and muscles. It increases in blood during condition of severe liver damage either as a result of necrosis or other modification leading to increased cellular permeability (Akinsanya, 2010). On the other hand, anti-fungal treated group, gallic acid at $1 \mathrm{ml} / 1$ and $3 \mathrm{ml} / 1$ recorded similar values lower to the negative control group.

\section{Conclusion}

From this study, gallic acid treated group at $1 \mathrm{ml} / 1$ and $2 \mathrm{ml} / 1$ on haematology, serum biochemistry and histology performed better 
than the standard (anti-fungal) used on a commercial scale but was more effective at a dosage level of $2 \mathrm{ml} / \mathrm{l}$.

It is thereby recommended that gallic acid should be incorporated at a level of $2 \mathrm{ml} / 1$ for positive control of aspergillosis in poultry production. Further studies on potential pharmacological, biochemical and physiological effects is imperative if the benefits of these botanicals are to be successfully harnessed.

\section{References}

Akinsanya, J.O. (2010). Response of turkey poults to graded levels of alphamune haematology, serum biochemistry and histology. American Journal of Clinical Nutrition, 72(1): 272S-279S.

Ayodele, O.I. (2009). A handbook of laboratory tests for health practitioners.

Babalola, T.O.O., Adebayo, M.A., Apata, D.F. and Omotosho, J.S (2009). Effect of dietary alternative lipid sources on heamatological parameters and serum constituents of Heterobranchus longifilis fingerlings. Trop. Anim. Health Prod., 41: 371 - 377.

Bailey, R.H., Kubena, L.F., Harvey, R.B., Buckley, S.A. and Rottinghaus, G.E., 1998. Efficacy of various inorganic sorbents to reduce the toxicity of aflatoxin and T-2 toxin in broiler chicks. Poultry Science. 77: 16231630.

Bolu, S.A., N. Elelu, R.N. Ahmed, F.E. Solaojo, K.F. Daramola, V.S. Omotosho, A.G. Atitebi and M. Afeni (2014). Effect of Vitamins, Amino Acids and Phyto-Active Biomolecules on Aspergillus flavus in Poultry Production

Bolu, S.A., Babalola, T.O., Elelu, N., Ahmed, R.N., Oyetunde, S.A., Ademola, P.F. and Jiddah, S.A. (2013). Effect of supplemental aloe vera gel in drinking water on some performance histology, hematology, serum constituents and growth of turkey poults challenged with Escherichia coli. Wudpecker Journal of Agricultural Research, 2(8): 223 - 229.

Duncan, D.B. (1955). Multiple Range and Ftest. Biometrics, 11: 1-42.

Elbarkouky, E.M., Mohammed, F.R., Atta, A.M., Abu Taleb, El Menawey, M.A. and Hatab, M.H. (2010). Effect of Saccharomyces cerevisiae and vitamin $\mathrm{C}$ supplementation on performance of broilers subjected to Ochratoxin A contamination. Egyptian Poultry Science, 30(1): 89-113.

Fukumoto, L.R. and Mazza, G. (2000). Assessing antioxidant and prooxidant activities of phenolic compounds. $J$. Agric. Food Chem. 48: 3597-3604

Gibbons, S. (2008). Phytochemicals for bacterial resistance - Strengths, weaknesses and opportunities. Planta Medica, 74: 594-602.

Gunckel, S., Santander, P., Cordano, G., Ferreira, J., Munoz, S., Nunez-Vergara, L.J. and Squella, J.A. (1998). Antioxidant activity of gallates: an electrochemical study in aqueous media. Chem-Biol. Interact. 114: 45-59.

Gustafson, R.H. and Bowen, R.E. (1997). Antibiotic use in animal agriculture. Journal of Applied Microbiology, 83: 531-541.

Gustavo, H., Goldman, S. and Osmani, A. (2007). The Aspergilli: Genomics, medical aspects, Biotechnology and research methods. Page 457: Production and Prevention of Aflatoxin in food and feed

Kececi, O., Oguz, H., Kurtoglu, V. and Demet, Ö. (1998). Effects of polyvinylpolypyrrolidone, synthetic zeolite and bentonite on serum biochemical and haematological characters of broiler chickens during aflatoxicosis. Br. Poult. Sci. 39: $452-$ 458. 
King, R.A., Creel, D., Cervenka, J., Okoro, A.N. and Witkop, C.J. (1980). Albinism in Nigeria with delineation of a new recessive oculocutaneous type. Clin Genet., 17: 259-270.

Klich, M.A. (1998). Soil fungi of some lowaltitude desert cotton fields and ability of their extracts to inhibit Aspergillus flavus, Mycopathologia 142, 97-100,

Lee, S.E., Park, B.S., Bayman, P., Baker, J.L., Choi, W.S. and Campbell, B.C. (2007). Suppression of ochratoxin biosynthesis by naturally occurring alkaloids. Food Addit. Contam., 24: 391-397.

Liu, Z.Q., Ma, L.P., Zhou, B., Yang, L. and Liu, Z.L. (2000). Antioxidative effects of green tea polyphenols on free radical initiated and photosensitized peroxidation of human low-density lipoprotein. Chem. Phys. Lipids, 106: 53-63.

Nizam, F. and Oguz, H. (2003). Occurance of aflatoxins in layer feed and corn samples in Konya Province, Konya. Food Addit. Contam., 20: 654-658

Palma, M. and Taylor, L.R. (1999). Extraction of polyphenolic compounds from grape seeds with near critical carbon dioxide. J. Chromatogr. A849: 117-124.

Park, J.W., Kim, E.K., Kim, Y.B. (2004). Estimation of the daily exposure of Koreans to aflatoxin B1 through food consumptions. Food Addit. Contam., 21: 70-75.

Pier, A.C. (1990). Micotoxinas y micotoxicosis. In: Biberstein EL, Zee YC. Tratado de microbiología veterinaria. España: Acribia,

Ravindran, V. (2006). Broiler nutrition in New Zealand - Challenges and Strategies. Accessed in 2/12/2006

Reynolds, L.D and Wilson, N.G. (1991). "Scribes and Scholars" $3^{\text {rd }}$ Ed. Oxford pp 193- 4.

Sanchez-Moreno, C., Larrauri, J.A. and Saura-Calixto, F. (1999). Free radical scavenging capacity and inhibition of lipid oxidation of wines, grape juices and related polyphenolic constituents. Food Res. Int. 32: 407-412.

Shahi, S., Patra, M., Shukia, A.C. and Dikshit, A. (2003). Use of essential oil as botanical pesticide against post harvest spoilage in Malus pumilo fruits. Biocontrol., 48: 223-232.

Shukla, S.K. and Pachaurri, S.P. (1995). Blood biochemical profiles in induced aflatoxicosis of cockerels, br. Poultry Science 63:15451-1

Steel, R.G.D. and Torrie, J.H. (1980). Principles and procedures of statistics: A biometrical approach 2nd Edition. McGraw Hill Book Co., N.Y. 27-54.

Tillson, D.M. (2003). In: Textbook of Small Animal Surgery. $3^{\text {rd }}$ edn. D. Slatter (ed) WB Saunders, Philadelphia. Pp 1046 1049.

Toghyani, M., Gheisari, A., Ghalamkari, G. and Eghbalsaied, S. (2011). Evaluation of cinnamon and garlic as antibiotic growth promoter substitutions on performance, immune responses, serum biochemical and haematological parameters in broiler chicks. Livest. Sci., 138: 167-173.

Tung, H.T., Wyatt, R.D., Thaxton, P. and Hamilton, P.B. (1975). Concentrations of serum proteins during aflatoxicosis. Toxicology and Applied Pharmacology. 34: 320 - 326.

Vagi, E., Simandi, B., Suhajda, A. and Hethelyi, E. (2005). Essential oil composition and antimicrobial activity of Origanum majorana L. extracts obtained with ethyl alcohol and supercritical carbon dioxide. Food Res. Int., 38: 51-57.

Zaky, Z.M., Salem, D.A., El-Ballal, S.S. and Meki, A.M.A. (1998). Effect of Staphylococcus aureus protein A and Freund's complete adjuvant on aflatoxin B1 toxicity in broilers. Wiener Tierarztliche Monatschrift. 85: 43 - 48. 